\title{
Dilution effects on microzooplankton in dilution grazing experiments
}

\author{
J. R. Dolan ${ }^{1,2, *}$, C. L. Gallegos ${ }^{1}$, A. Moigis ${ }^{1, * *}$ \\ ${ }^{1}$ Smithsonian Environmental Research Center, PO Box 28, Edgewater, Maryland 21037, USA \\ ${ }^{2}$ Marine Microbial Ecology Group, CNRS ESA 7076, Université Paris VI, Station Zoologique, BP 28, \\ 06230 Villefranche-sur-Mer, France
}

\begin{abstract}
In dilution experiments, filtered seawater is used to create a gradient of grazing pressure on phytoplankton. Microzooplankton grazing is estimated by examining phytoplankton growth within the gradient. However, the dilution series also represents a resource gradient for microzooplankton. Here we report the effects of dilution on grazers. In 2 standard dilution experiments, using communities from the eutrophic (chlorophyll $a=12$ to $15 \mu \mathrm{g} \mathrm{l}^{-1}$ ) Rhode River Estuary, we examined the effects of dilution on different groups of microzooplankters: rotifers, tintinnid ciliates, oligotrich ciliates, predacious ciliates, and Mesodinium rubrum. Apparent growth rates of tintinnids and oligotrichs varied with prey concentration, decreasing with the dilution factor from about $+0.5 \mathrm{~d}^{-1}$ in undiluted whole water to about $-1 \mathrm{~d}^{-1}$ in the $5 \%$ whole water, closely resembling numerical response curves. Among tintinnids, there was an increase in the relative abundance of larger tintinnids in the time $24 \mathrm{~h}$ samples of dilute treatments compared to the less dilute treatments. No consistent dilution effect was shown by rotifers or predacious ciliates. The growth rates of the photosynthetic ciliate $M$. rubrum increased with dilution, resembling the typical pattern of chlorophyll $a$ and autotrophic nanoplankton. Grazer growth in undiluted waters and grazer mortality in dilute water may be common and result in uncertainty in measured grazing rates. We urge that grazers be examined in grazing experiments not only to assess possible artifacts in grazing rate estimates, but also to provide information, beyond a simple grazing rate, on the grazer populations.
\end{abstract}

KEY WORDS: Ciliate · Oligotrich · Tintinnid · Phytoplankton · Nanoplankton · Rotifer · Flagellate

\section{INTRODUCTION}

In 1982, Landry \& Hassett introduced a dilution approach to the measurement of herbivory by microzooplankton in natural seawater communities (Landry \& Hassett 1982). Dilution reduces encounter rates between phytoplankton and their microzooplankton grazers. The method consists of amending natural assemblages of phytoplankton and grazers with varying proportions of filtered seawater creating a dilution series, and then estimating the grazing rate as the increase in apparent phytoplankton growth rate with

\footnotetext{
-E-mail: dolan@obs-vlfr.fr

**Present address: Ulmenstrasse 73, 24306 Ploen, Germany

the dilution factor. Specifically, the microzooplankton grazing rate is estimated as the slope of a regression of apparent phytoplankton growth in the various dilutions against dilution factor. The growth rate of the phytoplankton is estimated as the apparent growth rate extrapolated to $100 \%$ dilution (growth in the absence of grazers). The approach relies on relatively few assumptions: (1) phytoplankton growth rate is limited neither by nutrients nor by density dependence, (2) phytoplankton growth is exponential, and (3) consumption rates by microzooplankton are linear with respect to phytoplankton concentration.

The method requires little manipulation of natural communities other than dilution and the addition of nutrients when these are in short supply (to satisfy 


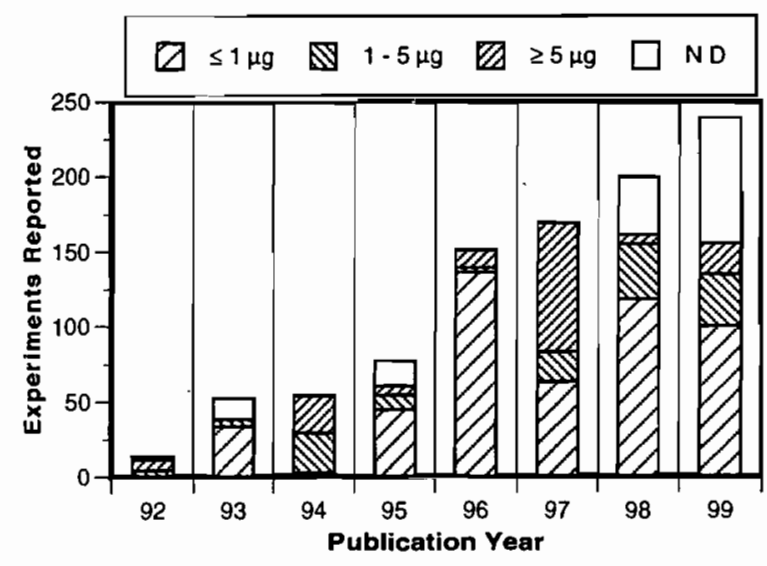

Fig. 1. Annual number of dilution experiments published from 1992 to 1999, reported in studies of marine and estuarine systems, classified by the initial chlorophyll concentration of the water used $\left(\mu \mathrm{g} \mathrm{l}^{-1}\right)$. Note the regular increases in the number of experiments reported and the large proportion conducted

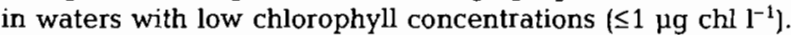
ND: no data or chlorophyll concentrations were not clearly relatable to individual experiments. Numbers of experiments include those with insignificant or negative grazing rates when reported. Data from 1992: Evans \& Paranjape, McManus \& Ederington-Cantrell, Verity \& Vernet. Data from 1993: Burkill et al. b,c, Harrison et al., Landry et al., Verity et al., Weeks et al. Data from 1994: Kamiyama, Neuer \& Cowles. Data from 1995: Burkill et al., Dagg, Fahnenstiel et al., Gifford et al., Landry et al. a,b, Sime-Ngando et al., Waterhouse \& Welschmeyer. Data from 1996: Ayukai, Boyd et al., Chavez et al., Froneman \& Perissinotto a,b, Froneman et al. a,b, Gallegos et al., Strom \& Strom, Verity et al. Data from 1997: Froneman \& McQuaid, Froneman et al., Gallegos \& Jordan a Latasa et al., Nejstgaard et al., Reckermann \& Veldhuis, Scharek et al., Tamigneaux et al., Tsuda \& Kawaguchi. Data from 1998: Ayukai \& Miller, Cotano et al., Froneman \& Balarin, James \& Hall, Landry et al., Lessard \& Murrell, Murrell \& Hollibaugh, Ruiz et al,, Schülter. Data from 1999: Brown et al., Caron \& Dennett, Edwards et al., Gaul et al., Johnson et al., Kuipers \& Witte, Lehrter et al., Rivkin et al.

Assumption 1). Given its simplicity, it is not surprising that the method has become increasingly popular in recent years, especially in open ocean waters of low chlorophyll content (Fig. 1). Dilution experiments are now a standard protocol for the estimation of microzooplankton herbivory (Burkill et al. 1993a, Landry 1993). Taxon- or pigment-specific mortality rates of phytoplankton have been estimated using the dilution method and HPLC measurements of pigments (e.g., McManus \& Ederington-Cantrell 1992, Verity et al. 1993, Fahnenstiel et al. 1995, Waterhouse \& Welschmeyer 1995, Verity et al. 1996, Latasa et al. 1997). The analysis of samples using flow cytometry has provided specific rates of mortality and growth for picoplankters such as Synechococcus and Prochlorococcus (e.g., Landry et al. 1995a, Reckerman \& Veldhuis 1997, Johnson et al. 1999). The approach has also been adapted for use in a wide variety of environments ranging from studies of bactivory in the benthos (Kemp 1994) to use in anoxic waters (Detmer et al. 1993), seaice melt ponds (Wickham \& Carstens 1998) and temperate lakes (Elser et al. 1995, Jones \& Young 1998).

Despite wide-spread adoption, the method is not without problems. Publications commonly report instances of uninterpretable results, i.e. plotting apparent phytoplankton growth against dilution factor does not yield a significant regression ( 0.05 level). When this phenomenon is reported, frequencies range from 6 to $66 \%$ of the experiments run (Kamiyama 1994, Gifford et al. 1995, Landry et al. 1995a, Reckermann \& Veldhuis 1997, Lessard \& Murrell 1998, Murrell \& Hollibaugh 1998, Caron \& Dennett 1999, Gaul et al. 1999, Kuipers \& Witte 1999). Some of these problematic results are likely due to the fact that slight slopes, or low grazing rates, are difficult to detect with regression analysis using the small ' $\mathrm{n}$ ' values commonly employed ( 8 to 15 ). Other possibilities concern violation of the assumptions underpinning dilution assays. As nutrients are often added or measurable, nonlinear relationships between phytoplankton mortality rates and the dilution factor appear the most probable explanation.

Problems which have received particular attention with regard to the consumption rates of microzooplankton include differences in the per-capita feeding rate of grazers in the different dilution treatments (Gallegos 1989, Evans \& Paranjape 1992) and the growth of grazers in the undiluted samples (Gallegos et al. 1996). Interestingly, the response of the grazer community to dilution in terms of apparent growth. and mortality, although recognized as a possible problem (Landry et al. 1995b), has not been explored in any detail. To our knowledge, only a single study has provided data on apparent changes in microzooplankton concentrations; all non-tintinnid taxa were combined and no consistent patterns were noted (Gifford 1988).

In this study, we examined the microzooplankton community in 2 dilution experiments in all the treatments ranging from 100 to $5 \%$ whole water. We found that (1) oligotrich and tintinnid ciliates, which generally dominate microzooplankton communities, showed apparent growth rates which varied in proportion to available nanoplanktonic prey, (2) there were obvious differences in the species composition of the tintinnid community, (3) apparent growth of Mesodinium rubrum increased with dilution factor, and (4) predacious ciliates (Didinium, Cyclotrichium) and rotifers (Synchaeta spp.) showed no consistent changes in relation to dilution. The combined effects of grazer mortality in dilute treatments and growth in undiluted treatments confound estimates of grazing rate and the phenomenon may be common. 


\section{METHODS}

Study site. Dilution experiments were run in the Rhode River Estuary ( $\left.38^{\circ} 53^{\prime} N, 76^{\circ} 32^{\prime} \mathrm{W}\right)$, a eutrophic subestuary of the Chesapeake Bay. Detailed data on the compositions, concentrations, and seasonal cycles of nutrients, phytoplankton, and zooplankton have appeared previously (Dolan \& Gallegos 1991, 1992, Gallegos et al. 1992, 1997, Gallegos \& Jordan 1997a,b, Jordan et al. 1991a,b).

Experimental protocol. A standard dilution experiment protocol, used regularly for several years, was employed (see Gallegos \& Jordan 1997a). Briefly, duplicate 21 polycarbonate bottles were used to incubate whole estuarine water at 5 dilution levels: 100,80 , 40,20 , and $5 \%$ whole water, diluted with GF/F-filtered water. All whole water aliquots were drawn from a single, well-mixed carboy, including samples for initial concentrations of nutrients, chlorophyll and microrganismal abundances. Nutrient salts $\left(\mathrm{NaNO}_{3}\right.$ and $\mathrm{Na}_{2} \mathrm{HPO}_{4}$ ) were added to the bottles to yield final concentrations of $60 \mu \mathrm{M} \mathrm{NO}{ }_{3}$ and $6 \mu \mathrm{MPO}_{4}$. In Expt 1 additional bottles of whole water without nutrients added were incubated to check for nutrient effects on grazers. The bottles were incubated in situ at a depth of $1 \mathrm{~m}$ for $24 \mathrm{~h}$, retrieved and returned to the laboratory for time $24 \mathrm{~h}\left(t_{24}\right)$ sampling.

Sample analysis. Samples for chlorophyll analysis were filtered onto GF/F glass fiber filters and, following acetone extraction, the concentrations were determined using a Turner Designs 10-AU fluorometer. Nutrient analysis methods followed standard protocols outlined in Jordan et al. (1991a). Sample aliquots of 20 or $40 \mathrm{ml}$ for enumerations of nanoplankton and bacteria were fixed with ice-cold glutaraldehyde $11 \%$ final conc.). Bacteria, and autotrophic and heterotrophic nanoplankton were counted using an epifluorescence microscope and DAPI-stained preparations following standard protocols (e.g., Dolan \& Gallegos 1991). For ciliate enumerations, sample aliquots of $50 \mathrm{ml}$ (Initial, $t_{24} 100$, and $80 \%$ whole water) or $500 \mathrm{ml}$ ( $t_{24}$ samples for $40,20,5 \%$ whole water) were fixed with acid Lugol's ( $2 \%$ final conc). Prior to settling in inverted microscope sedimentation chambers, the $500 \mathrm{ml}$ samples were pre-concentrated to $75 \mathrm{ml}$ volumes by first settling in $500 \mathrm{ml}$ graduated cylinders for 48 to $72 \mathrm{~h}$, followed by slowly siphoning off the top $425 \mathrm{ml}$. We have used this pre-concentration method extensively and found no significant loss of ciliates (Dolan \& Marrasé 1995, Dolan et al. 1999). Single or multiple $10 \mathrm{ml}$ subsamples, providing raw counts of at least 100 oligotrichs and 100 tintinnids, were examined using an inverted microscope. Parallel samples of whole water $(25 \mathrm{ml})$ from initial water samples were fixed with glutaraldehyde and Lugol's and then examined with an inverted microscope equipped with epifluorescence to permit the classification of oligotrich morphotypes, distinguishable in Lugol's-fixed material, as either mixotrophic or heterotrophic, based on chlorophyllfluorescence visible in glutaraldehyde-fixed individuals. Ciliates were placed in the categories of: mixotrophic oligotrichs, heterotrophic oligotrichs, tintinnids, predacious ciliates (Didinium spp., Cyclotrichium spp.), Mesodinium rubrum and others (mostly Balanion spp., Euplotes spp.). For rotifers, samples ranging from 200 to $400 \mathrm{ml}$ were concentrated to $20 \mathrm{ml}$ through a $20 \mu \mathrm{m}$ mesh nitex screen and 2 to $20 \mathrm{ml}$ aliquots of this concentrate, providing raw counts of at least 100 rotifers, were settled and examined using an inverted microscope.

Data analysis. The apparent growth rates in individual bottles were calculated as $\ln \left(\right.$ conc $_{24} /$ conc $\left._{0}\right)$, where conc $_{24}$ and conc $_{0}$ are, respectively, the final measured concentration and the initial concentration, based on initial whole water concentration and dilution factor. Regression analysis of apparent growth rates against 'fraction unfiltered water' was run using Statview 4.5. Regression analysis was also used to relate apparent phytoplankton (as chlorophyll) growth rates to different measures of grazing pressure (as opposed to fraction unfiltered or dilution factor) in the individual containers. As measures of grazing pressure we considered: (1) ciliate concentration at $t_{24}$ as $\% t_{0}$ whole water concentration, and (2) a measure of average ciliate concentration, following Gallegos et al. (1996), estimated as the geometric mean predator density (GMPD) calculated as $\left[t_{0} \text { conc } \times t_{24} c o n c\right]^{0.5}$, converted to $\% t_{0}$ ciliate concentration. For these calculations, ciliate concentration was considered as total ciliates, with the exception of Mesodinium rubrum. We recognize that both apparent growth rates and ciliate concentrations, unlike 'fraction unfiltered', cannot be measured without error, and therefore correlation rather than regression should be used-we did so only to estimate potential error in ignoring actual predator concentrations.

We also estimated grazing rates by comparing the 2 extremes of the dilution series. The additional grazing estimates, which we term ' 100 versus $5 \%$ ', were calculated using data only from the 100 and $5 \%$ whole water treatments, by considering the containers, respectively, as representing vessels with and without grazers. A 'raw 100 versus $5 \%$ ' grazing rate, $g \mathrm{~d}^{-1}$, was calculated as the difference between apparent chlorophyll growth rates in each container with and without grazers (average apparent growth rate in the 0.05 dilution factor containers). An 'adjusted 100 versus $5 \%$ ' rate, corrected for grazer growth during the experiment was also calculated. The correction for grazer growth consisted of first calculating a per-capita graz- 
ing rate by dividing the 'raw 100 versus $5 \%$ ' grazing rate by the average number of grazers in the containers (GMPD), and then multiplying the resulting percapita rate by the initial concentration of grazers (for our purposes only ciliates were considered) to obtain a grazing rate corrected for the growth of grazers in the containers. Finally, in the second experiment the plot of phytoplankton apparent growth rate against dilution factor indicated nonlinear feeding kinetics by the microzooplankton (Gallegos 1989). For that experiment we also estimated $g$ using Eq. (11) in Gallegos (1989).

\section{RESULTS}

Physical and chemical data for the dilution experiments are given in Table 1. End of experiment nutrient samples were not taken for Expt 1, but Expt 2 samples indicated that most of the added nutrients were utilized in all the dilutions (Table 1). Initial and final organismal concentrations for undiluted samples appear in Table 2. The comparison of ciliate concentrations in bottles with and without added nutrients (Expt 1) showed no differences (data not shown).

In both Expt 1 (Fig. 2) and Expt 2 (Fig: 3), apparent growth rates of phytoplankton (based on chlorophyll), photosynthetic nanoplankton-ANAN, and the photosynthetic ciliate Mesodinium rubrum were highest in dilute waters and decreased with the proportion of whole water or 'fraction unfiltered'. For chlorophyll growth rates in Expt 2, this decrease appeared nonlinear with no further decrease above dilution factor $=$ $40 \%$ (Fig. 3). In contrast, an opposite trend of growth rate (increasing with fraction unfiltered) was evident for tintinnids and heterotrophic oligotrichs. The apparent growth rates of mixotrophic oligotrichs (Expt 1 only), predacious ciliates, heterotrophic nanoplankton and rotifers varied irregularly. Regression statistics of the relationships with 'fraction unfiltered' given in Table 3 indicated the strongest relationships between 'fraction unfiltered', or dilution factor, and growth rates of oligotrichs and tintinnids. In both experiments, the overall range of net growth rates was wider for ciliates than for chlorophyll (Figs. $2 \& 3$; note change in scale for chlorophyll plots).

For the dominant taxa of oligotrichs and tintinnids in each experiment, apparent growth rates plotted against initial nanoplankton prey concentration (PNAN + ANAN) in the various treatments yielded numerical response curves with a typical hyperbolic shape (Fig. 4). Converting nanoplankton concentrations into carbon units by assigning the value of $11 \mathrm{pg}$ C nanoplankter ${ }^{-1}$ (avgerage biovolume of $55 \mu \mathrm{m}^{3} \times$

Table 1. Physical and chemical characteristics of waters employed in the dilution experiments. For Expt 2 final $\left(t_{24}\right)$ nutrient concentrations are given $\pm \mathrm{SE}$ of the 10 bottles. nd: no data

\begin{tabular}{|c|c|c|c|c|c|}
\hline & $\mathrm{T}\left({ }^{\circ} \mathrm{C}\right)$ & Salinity $(\%)$ & $\mathrm{NH}_{4}(\mu \mathrm{M})$ & $\mathrm{NO}_{3}(\mu \mathrm{M})$ & $\mathrm{PO}_{4}(\mu \mathrm{M})$ \\
\hline \multicolumn{6}{|l|}{ Expt 1: October 10, 1999} \\
\hline Initial & 18.6 & 13.2 & 9.6 & 0.5 & 0.2 \\
\hline$t_{0}$ after adding nutrients & & & 9.6 & 60 & 6 \\
\hline$t_{24}$ & 17.9 & nd & nd & nd & nd \\
\hline \multicolumn{6}{|l|}{ Expt 2: October 19, 1999} \\
\hline Initial & 16.4 & 13.1 & 4.5 & 0.3 & 0.1 \\
\hline$t_{0}$ after adding nutrients & & & 4.5 & 60 & 6 \\
\hline$t_{24}$ & 16.1 & nd & $4.8 \pm 0.21$ & $2.8 \pm 1.75$ & $0.6 \pm 0.08$ \\
\hline
\end{tabular}

Table 2. Organismal concentrations in Expts 1 and 2, in undiluted waters at the beginning $\left(t_{0}\right)$ and end $\left(t_{24}\right)$ of the experiments of chlorophyll $a$ in $\mu \mathrm{g} \mathrm{l}^{-1}$ (Chl a), phototrophic nanoplankton $\times 10^{-3} \mathrm{ml}^{-1}$ (PNAN), heterotrophic nanoplankton $\times 10^{-3} \mathrm{ml}^{-1}(\mathrm{HNAN}$ ), heterotrophic bacteria $\times 10^{-6} \mathrm{ml}^{-1}$ (Bacteria), total ciliates excluding Mesodinium rubrum ml ${ }^{-1}$ (Ciliates), $M$. rubrum ml (M. rubrum) and rotifers $\mathrm{ml}^{-1}$ (Rotifers). Concentrations at $t_{24}$ are averages of the duplicate bottles

\begin{tabular}{|c|c|c|c|c|c|c|c|}
\hline & $\mathrm{Chl} \mathrm{a}$ & PNAN & HNAN & Bacteria & Ciliates & M. rubrum & Rotifers \\
\hline \multicolumn{8}{|c|}{ Expt 1: October 10, 1999} \\
\hline Whole water $t_{0}$ & 14.8 & 17.9 & 6.9 & 6.1 & 31.5 & 53.9 & 2.0 \\
\hline Whole water $t_{24}$ & 22.0 & 35.9 & 6.2 & 8.2 & 43.6 & 17.9 & 2.9 \\
\hline \multicolumn{8}{|c|}{ Expt 2: October 11, 1999} \\
\hline Whole water $t_{0}$ & 12.7 & 53.9 & 12.5 & 6.3 & 30.4 & 38.8 & 2.4 \\
\hline Whole water $t_{24}$ & 19.4 & 90.3 & 4.7 & 4.8 & 33.3 & 20.4 & 2.1 \\
\hline
\end{tabular}




\section{EXPERIMENT 1}
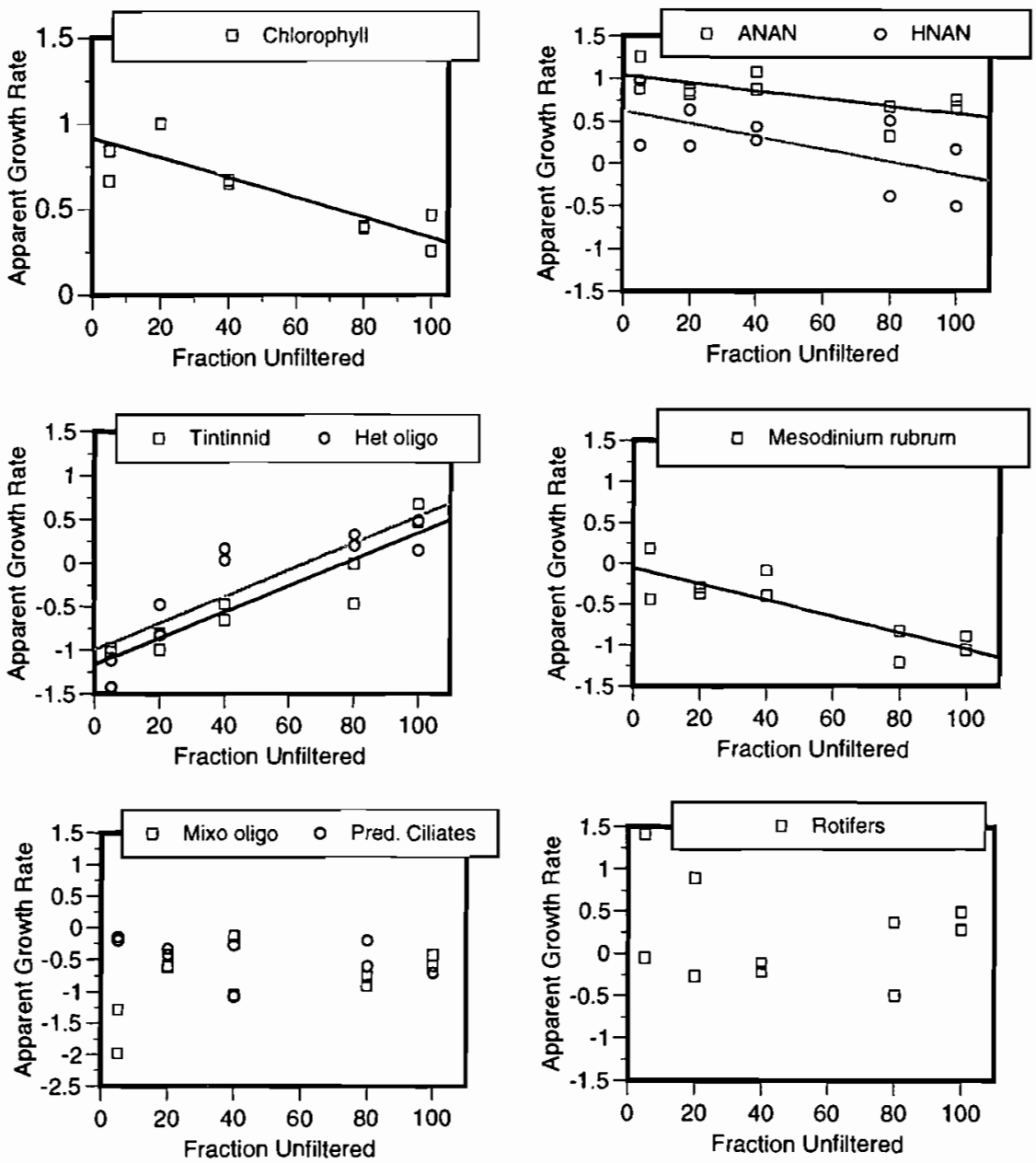

Fig. 2. Dilution plots from Expt 1. Apparent growth rates increased with dilution factor for chlorophyll, autotrophic nanoplankton (ANAN), heterotrophic nanoplankton (HNAN), and Mesodinium rubrum. In contrast, the growth rates of tintinnids and heterotrophic oligotrichs (Het oligo) declined and no clear effect of dilution was shown by rotifers, mixotrophic oligotrich (Mixo oligo) or predacious ciliates (Pred. Ciliates). Regression parameters are given in Table 3

$0.2 \mathrm{pg} \mathrm{C} \mu \mathrm{m}^{-3}$ ) indicates threshold prey concentrations (below which growth $=0$ ) ranging from 20 to $100 \mathrm{ng} \mathrm{C}$ $\mathrm{ml}^{-1}$ and saturating prey concentrations (above which growth rate does not increase) of 100 to $300 \mathrm{ng} \mathrm{C} \mathrm{ml}^{-1}$.

The examination of $t_{24}$ samples showed distinct differences between dilution treatments in the composition of tintinnid ciliate communities. There appeared to be a shift within the tintinnid community in both experiments, towards an increase in the dominance of species with larger loricas in the more dilute treatments, reflected in increases in average lorica length of the tintinnid community (Figs. $5 \& 6$ ). In the most dilute treatments, none of the tintinnid species showed positive apparent growth, therefore the changes in tintinnid community composition reflect differential survival of different species rather than differential growth.
As a metric of grazing pressure, using the regression of dilution factor against apparent chlorophyll growth rates gave higher grazing rate estimates than regressions against ciliate concentrations, either time-averaged or at the end of incubation (Table 4). Specifically, grazing rate estimates made using time-averaged (GMPD) ciliate concentrations, appropriate when the prey concentration is in the linear response range of the microzooplankton, were $93 \%$ of the rates estimated using the dilution factor for Expt 1. Regressions of end-point ciliate concentrations against apparent growth rates yielded grazing estimates equal to 81 and $63 \%$ of the dilution factor estimates for Expts 1 and 2 , respectively. Grazing rate estimates based on the difference between phytoplankton growth in whole water and $5 \%$ whole water, i.e. 'raw 100 versus $5 \%$ ', gave rates equivalent to 67 and $103 \%$ of the dilution 


\section{EXPERIMENT 2}
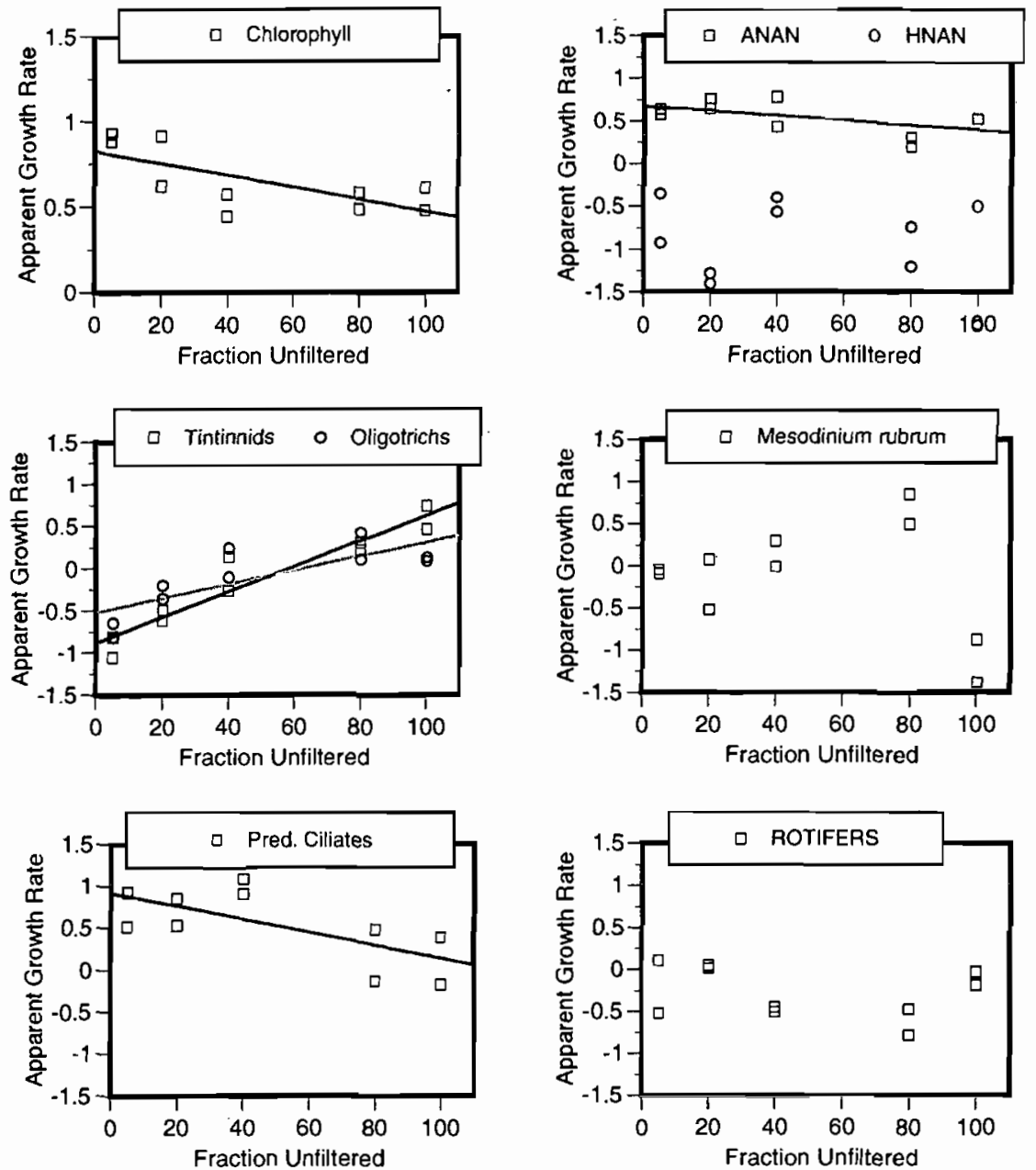

Fig. 3. Dilution plots from Expt 2. Apparent growth rates increased with dilution factor for chlorophyll, autotrophic nanoplankton (ANAN), and predacious ciliates (Pred. Ciliates). As in Expt 1, the growth rates of tintinnids and heterotrophic oligotrichs declined and no clear effect of dilution was shown by heterotrophic nanoplankton (HNAN), or Mesodinium rubrum. All oligotrichs were grouped in the experiment as mixotrophic forms were not easily distinguished from heterotrophic forms. Regression parameters are given in Table 3

Table 3. Parameters of regression relationships between dilution (fraction unfiltered) and apparent growth rates of phytoplankton ( $\mathrm{Chl} \mathrm{a),} \mathrm{phototrophic} \mathrm{nanoplankton} \mathrm{(PNAN),} \mathrm{heterotrophic} \mathrm{nanoplankton} \mathrm{(HNAN),} \mathrm{all} \mathrm{ciliates} \mathrm{excluding} \mathrm{Mesodinium} \mathrm{rubrum}$ (Total ciliates), all oligotrichs (Oligotrichs), all tintinnids (Tintinnids), Mesodinium rubrum ( $M$. rubrum), predacious ciliates (Pred. cils) and rotifers (Rotifers). Significant relationships are shown in bold; $\mathrm{n}=10$ for all analyses

\begin{tabular}{|c|c|c|c|c|c|c|c|c|c|}
\hline & $\mathrm{Chl} \mathrm{a}$ & PNAN & HNAN & Total ciliates & Oligotrichs & Tintinnids & M. rubrum & Pred. cils & Rotifers \\
\hline \multicolumn{10}{|c|}{ Expt 1: October 10, 1999} \\
\hline Slope & -0.6 & -0.4 & -0.7 & 1.3 & 1.5 & 1.5 & -1.0 & -0.4 & -0.3 \\
\hline $\mathbf{r}^{2}$ & 0.73 & 0.45 & 0.41 & 0.83 & 0.63 & 0.87 & 0.72 & 0.23 & 0.20 \\
\hline Probability & 0.002 & 0.033 & 0.045 & 0.001 & 0.007 & 0.001 & 0.002 & 0.166 & 0.582 \\
\hline \multicolumn{10}{|c|}{ Expt 2: October 11, 1999} \\
\hline Slope & -0.3 & -0.3 & -0.3 & 1.1 & 0.9 & 1.4 & -0.5 & -0.8 & -0.2 \\
\hline$r^{2}$ & 0.50 & 0.33 & 0.25 & 0.85 & 0.65 & 0.89 & 0.05 & 0.47 & 0.05 \\
\hline Probability & 0.023 & 0.083 & 0.546 & 0.001 & 0.005 & 0.001 & 0.145 & 0.028 & 0.519 \\
\hline
\end{tabular}



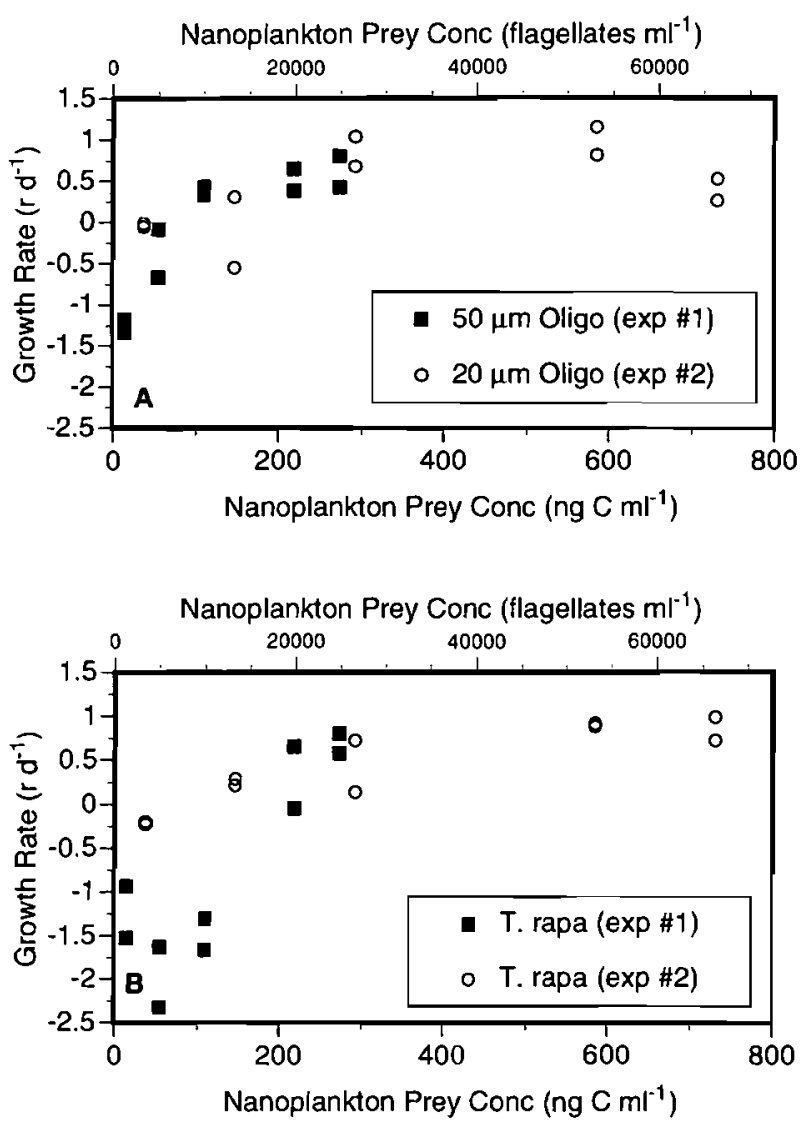

Fig. 4. Apparent growth rate of numerically dominant oligotrichs and tintinnids in the dilution experiments as a function of initially available nanoplankton prey. (A) Oligotrich growth rates: in Expt 1 for a $50 \mu \mathrm{m}$ long conical Strombidium sp., in Expt 2 for a spherical $20 \mu \mathrm{m}$ diameter Strombidium sp. (B) Growth rates of the tintinnid Tintinnopsis rapa in Expts 1 and 2

factor rates, and the adjusted 100 versus $5 \%$ rates were 67 and $86 \%$ of the dilution factor rates. In contrast, both the phytoplankton growth rate and microzooplankton grazing rate in Expt 2 were higher when calculated according to nonlinear feeding kinetics (Table 4). This appears to result from the formulation of Eq. (11) of Gallegos (1989), which calculates $g$ for initial conditions of the experiment, while accounting for the fact that per-capita grazing declines during the course of the experiment when feeding is nonlinear and phytoplankton prey density is increasing (i.e. there was a positive net growth rate of phytoplankton in Expt 2, Fig. 3).

\section{DISCUSSION}

Our experimental results show that within a dilution series considerable apparent growth and mortality can occur among ciliates, and different functional groups of ciliates display distinct patterns of growth and mortality. Typical grazers of nanoplankton, oligotrichs and tintinnids, showed rates of growth and mortality which co-varied with the availability of nanoplankton prey (e.g., Fig. 4). Clear differences between dilution treatments were evident in the composition of the tintinnid community at the end of the experiments (Figs. $5 \& 6$ ), likely due to lower mortality rates of larger tintinnids compared to small species in the dilute treatments. Predacious ciliates, raptorial feeders on dinoflagellates and small ciliates (Dolan 1991), exhibited a different pattern, showing either no clear trend (Fig. 2) or increases in apparent growth rates with dilution (Fig. 3). As we did not sample all the dilution treatments at $t_{0}$ we can only describe growth rates as apparent growth rates. However, at the end of the experiments, the ciliate community composition certainly differed between the different dilution treatments, and to the extent that different ciliate taxa ingest different prey items, grazing patterns would vary between dilution treatments.

Attempts to extrapolate experimental findings of patterns of selective grazing to in situ populations would be complicated considerably by qualitative differences in grazer communities between different dilution treatments, and between the $t_{0}$ and $t_{24}$ communities. Dilution experiments have often been employed to examine not only rates, but also specific patterns of microzooplankton grazing. Dilution experiments have been used to provide estimates of mortality rates with regard to different size-fractions of phytoplankton (Kamiyama 1994, Gifford et al. 1995. Froneman \& Perissinotto 1996a,b, Froneman et al. 1996a,b, Gallegos et al. 1996, Strom \& Strom 1996. Froneman \& McQuaid 1997, James \& Hall 1998, Kuipers \& Witte 1999). For individual phytoplankton taxa, many mortality rate estimates have been from dilution experiments with microscopically identified taxa (e.g., Landry et al. 1993, Fahnenstiel et al. 1995, Murrell \& Hollibaugh 1998, Rivkin et al. 1999) using pigment data (e.g., McManus \& Ederington-Cantrell 1992, Verity et al. 1993, 1996, Waterhouse \& Welschmeyer 1995, Latasa et al. 1997) or by flow cytometry (Landry et al. 1995a,b, 1998, Brown et al. 1999). Our results show distinct differences between grazer communities at the beginning and end of dilution experiments. One might expect the relative importance of grazing by 'starvation-resistant forms' (e.g., small metazoans, large tintinnids, predacious ciliates) to be exaggerated compared to the natural grazer communities in dilution experiments. Therefore, evidence of selective grazing by microzooplankton, based on differences in mortality rates of certain size-fractions of chlorophyll or individual taxa, in dilution experiments 


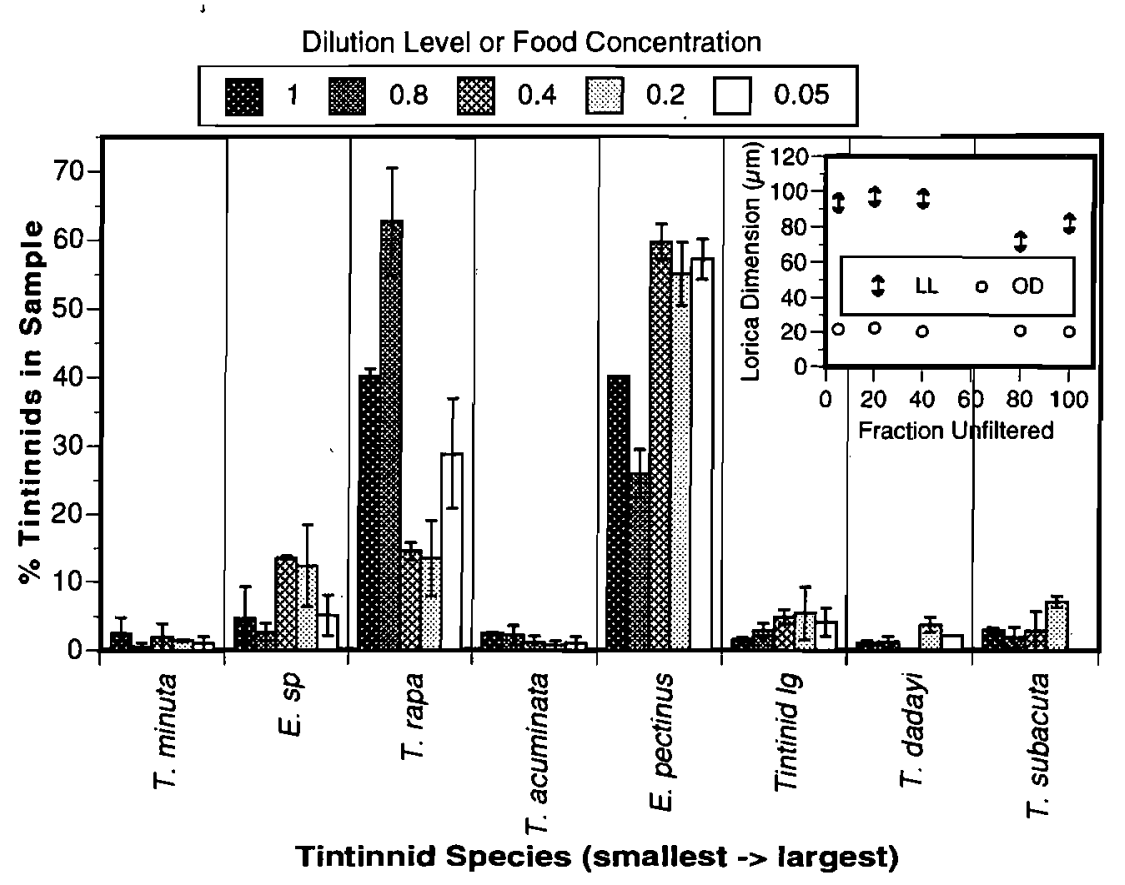

Fig. 5. Expt 1. Composition of the tintinnid ciliate community in the different dilution treatments $(1$ to 0.05$)$ in the $t_{24}$ samples. Error bars show the range of the \% values in the duplicate samples. Tintinnopsis species appear as 'T.', Eutintinnus species as 'E.', E. sp is about $50 \mu \mathrm{m}$ in length. Tintinnidium $\lg$ is a large Tintinnidium species, possibly $T$. mucicola. Note the declines in the relative importance of most of the smaller species with dilution factor. Inset graph shows overall averages of tintinnid lorica dimensions in the dilution treatments, oral diameter (OD) and lorica length (LL). Average LL was greatest in highly diluted waters with low food concentrations

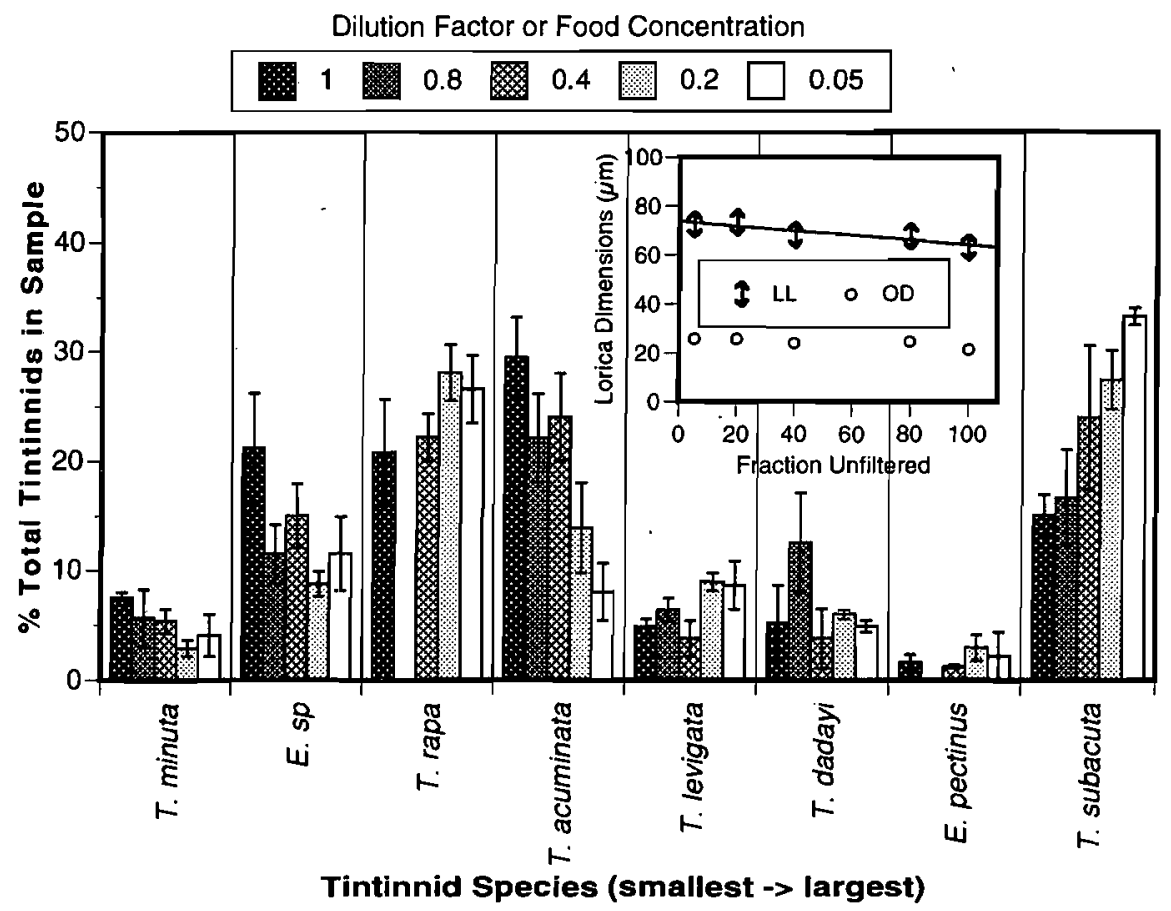

Fig. 6. Expt 2. Composition of the tintinnid ciliate community in the different dilution treatments (1 to 0.05$)$ in the $t_{24}$ samples. Error bars show the range of the \% values in the duplicate samples. Species as in Fig. 5. Similar to data from Expt 1 (Fig. 5), smaller species formed a smaller portion of the tintinnid community in samples from the more dilute treatments. Inset graph shows overall community averages of tintinnid lorica dimensions in the dilution treatments, oral diameter (OD) and lorica length (LL). Similar to the trend found in Expt 1, average LL increased as food levels decreased, and in this case average LL was significantly related to the fraction unfiltered $(p<0.05)$ 
Table 4. Comparison of estimates of grazing rates $(g)$, phytoplankton growth $(k)$ and the ratio of grazing to growth $(g / k)$ calculated by regression of apparent chl a growth against (1) dilution factor, (2) average ciliate concentrations (geometric mean predator density [GMPD]), (3) ciliate concentrations at the end of the experiment ( $t_{24}$ [ciliates]). Additional rate estimates were calculated comparing apparent chlorophyll growth in bottles of undiluted water versus $5 \%$ whole water, either uncorrected for ciliate growth (Raw 100 vs $5 \%$ ) or corrected (Adj 100 vs $5 \%$ ). For Expt 2, grazing was also calculated using the Gallegos (1989) equation which corrects for nonlinear feeding kinetics (NLFK). Rates given $\pm \mathrm{SE}$

\begin{tabular}{|lcccccc|}
\hline & Dilution factor & GMPD & $t_{24}$ [ciliates] & Raw 100 vs 5\% & Adj 100 vs 5\% & NLFK \\
\hline Expt 1, $g$ & $0.58 \pm 0.13$ & $0.54 \pm 0.13$ & $0.47 \pm 0.14$ & $0.39 \pm 0.10$ & $0.39 \pm 0.13$ & \\
Expt $2, g$ & $0.35 \pm 0.12$ & $0.27 \pm 0.10$ & $0.22 \pm 0.09$ & $0.36 \pm 0.07$ & $0.30 \pm 0.05$ & 0.42 \\
Expt $1, k$ & $0.92 \pm 0.08$ & $0.87 \pm 0.08$ & $0.82 \pm 0.08$ & $0.75 \pm 0.09$ & $0.75 \pm 0.09$ & 0.91 \\
Expt 2, $k$ & $0.82 \pm 0.08$ & $0.80 \pm 0.07$ & $0.79 \pm 0.07$ & $0.91 \pm 0.02$ & $0.91 \pm 0.02$ & 0.52 \\
Expt $1, g / k$ & 0.63 & 0.62 & 0.57 & 0.52 & 0.33 & 0.46 \\
Expt 2, $g / k$ & 0.43 & 0.34 & 0.28 & 0.40 & & \\
\hline
\end{tabular}

should be viewed with caution as the experiments may be biased in favor of starvation-resistant grazers.

In our experiments, not only did ciliate community composition differ among treatments, but the final ciliate abundance deviated considerably from dilution factor. A large part of the deviation of ciliate abundance from dilution factor was due to apparent growth and mortality of oligotrichs and tintinnids. In both experiments, the numerically dominant oligotrich and tintinnid showed differences in apparent growth rates among treatments, which closely resembled classic numerical response curves when growth rates were plotted as a function of prey concentration (Fig. 4). Despite slightly lower initial chlorophyll concentration (Table 2), the nanoplankton prey concentrations in Expt 2 were substantially higher than those in Expt 1 (Fig. 4), coinciding with the observation of nonlinear feeding kinetics (Fig. 3). Ciliate growth rates in Expt 2 appeared saturated at the 3 highest dilution factors (Fig. 4), which was the same range of dilution factors in which chlorophyll growth rates no longer declined. To our knowledge, this is the first demonstration of congruence between nonlinear feeding responses as inferred from apparent growth rates of phytoplankton with numerical response curves of ciliate grazers.

For the 2 numerically dominant oligotrich species, estimating threshold and saturating concentrations of prey gave values falling well within the range of reported values (Fig. 7). While it should be noted that published data may be biased towards 'easily cultured' oligotrichs, the growth responses of the oligotrichs in our experiments did not appear unusual.
Likewise, maximum mortality rates estimated as apparent growth rates of -1.0 to $-1.5 \mathrm{~d}^{-1}$ are not unusual, although little comparative data exist (see Montagnes 1996, Jeong et al. 1999, Montagnes \& Lessard 1999). These high mortality rates are likely due to high weight-specific metabolic rates of oligotrichs. For example, the heterotrophic oligotrich Strobilidium spiralis respires $2.8 \%$ of cell carbon $\mathrm{h}^{-1}$ at $20^{\circ} \mathrm{C}$ (Stoecker \& Michaels 1991), and in mixotrophic oligotrichs respiration rates range from 1 to $5 \%$ cell carbon $\mathrm{h}^{-1}$ (Crawford \& Stoecker 1996). If ciliates are unable to replenish cell carbon due to insufficient prey and are respiring $3 \%$ of cell carbon $\mathrm{h}^{-1}$, they would likely suffer high mortality rates within $24 \mathrm{~h}$.

The apparent result of ciliate growth in the undiluted or slightly diluted vessels, and mortality in the high dilution treatments was, that dilution factor was a poor
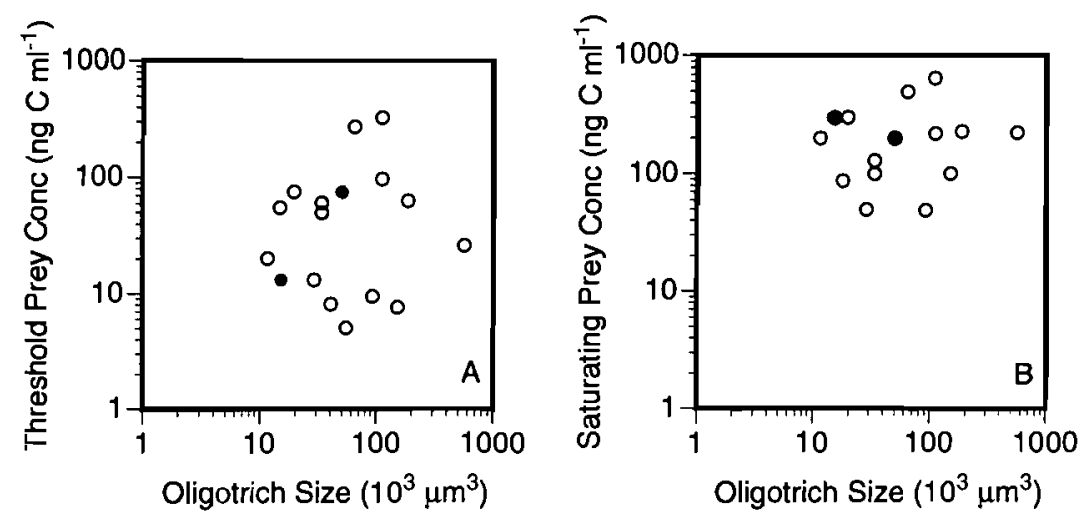

Fig. 7. Threshold and saturating prey concentrations of oligotrichs: comparison of the dominant oligotrichs (see Fig. 4) in the dilution experiments (•) with threshold and saturating prey concentrations $(0)$ reported for a variety of oligotrichs (data from Montagnes 1996, Jeong et al. 1999, Montagnes \& Lessard 1999). Note that growth response parameters of the oligotrichs from the dilution experiments do not appear unusual. Interestingly, for oligotrichs, neither minimum nor saturating prey concentrations appear to be related to oligotrich size; overall averages are $75 \mathrm{ng} \mathrm{C} \mathrm{m}^{-1}$ for threshold prey concentration and $222 \mathrm{ng} \mathrm{C}$ $\mathrm{ml}^{-1}$ for saturating prey concentration 
predictor of ciliate concentration or ciliate grazing pressure. Comparison of grazing rate estimates made using dilution factor or estimates of ciliate concentration suggested that ignoring changes in ciliate concentrations overestimates grazing rates (Table 4). Rates based on simple differences between phytoplankton growth in whole water and growth in highly diluted water (100 vs $5 \%$ ) were also lower than grazing rates based on dilution factor, with the exception of the 'raw 100 versus $5 \%$ ' rate for Expt 2 (Table 4 ). In contrast, the grazing rate calculated on the basis of nonlinear kinetics in Expt 2 was the highest of all. Thus, while dilution is an elegant and relatively non-intrusive manipulation of the plankton community, the impacts of dilution on community structure are evidently more far ranging than commonly recognized. The effects of these changes on grazing rate estimates need further elucidation with modeling studies of more complex food webs.

For the estimates based on differences in 100 versus $5 \%$ whole water, the use of $5 \%$ whole water to measure phytoplankton growth in the absence of grazers might appear as perhaps providing underestimates. However, Gallegos \& Jordan (1997a) demonstrated that apparent growth rate of phytoplankton in highly diluted incubations (fraction unfiltered $=0.05$ ) was a close approximation to the intrinsic growth rate determined by solution of the growth equations, whether linear or nonlinear (Gallegos 1989). Our results showing grazer mortality at high dilution indicate that the approximation succeeds because 0.05 is close to 0 functionally as well as mathematically. That is, grazing pressure in a $95 \%$ diluted incubation is even closer to 0 than would be predicted for a dilution factor of 0.05 . This result should be robust in waters of all trophic states. It might be difficult to apply growth measured by changes in pigment concentrations in waters of very low chlorophyll concentrations, but filtration or sample volumes are easily adjusted to increase detection limits when examining autofluorescent picoplankton by microscopy or flow cytometry.

The magnitudes of the differences found in grazing rate estimates, rates 63 to $93 \%$ of dilution factor rates (without the exception noted above), may appear modest but differences in growth and mortality we found in different dilution treatments, which occurred beginning with chlorophyll-rich waters, could be expected to be larger when working in waters with low chlorophyll concentrations. For example, consider an average threshold prey concentration, below which mortality occurs, of about $75 \mathrm{ng}$ carbon $\mathrm{ml}^{-1}$ for known oligotrichs (Fig. 7). If chlorophyll-containing prey represent but half the ciliate's ration and the carbon to chlorophyll ratio is 50 , mortality will occur at chlorophyll concentrations below $0.75 \mu \mathrm{g}$ chlorophyll $\mathrm{l}^{-1}$. It should be admitted that such calculations involve a considerable amount of uncertainty and our knowledge of numerical response parameters is perhaps not based on forms characteristic of all wild populations. However, these rough calculations support the view that gradients of ciliate growth and mortality, which lead to an overestimation of grazing rates, possibly occur when dilution series bracket chlorophyll concentrations of $1 \mu \mathrm{g}$ chlorophyll $1^{-1}$ or less

We have argued that dilution experiments can yield grazing patterns different from natural communities due to changes in the grazer community during the experiment. This possibility has long been recognized (Landry 1993). We have also argued that dilution experiments probably overestimate ciliate grazing rates, especially in low chlorophyll waters, using our experimental data and consideration of known threshold prey concentrations of oligotrichs. Previously, potential problems identified with the dilution approach were the artifacts resulting from changes in grazer abundance in undiluted water (e.g., Gallegos et al. 1996) and changes in individual grazer activities (Gallegos 1989, Evans \& Paranjape 1992). Thus, grazer growth in undiluted water is occasionally verified (e.g., Landry et al. 1993, Verity et al. 1993), and nonlinear feeding responses are now commonly considered. Here we have focused on the phenomenon of different changes in grazer abundances in the different dilution treatments.

Aggregate grazer activity, in the form of disappearance rates of fluorescently labelled bacteria (FLB), has been examined in different dilution treatments (Landry et al. 1995b). In experiments using waters of the central equatorial Pacific Ocean, in which Prochlorococcus and Synechococcus dominate the phytoplankton, average grazing rates from regressions of apparent phytoplankton growth against 'relative grazing' from FLB disappearance, while not significantly different, were lower than rates based on 'dilution factor' (Landry et al. 1995b, Table 3). Interestingly, such results suggest that 'dilution effects' may be less severe among grazers of picoplankton, presumed by most authors to be heterotrophic nanoflagellates (Dolan \& Simek 1999).

Beyond detection of possible artifacts in grazing experiments, the examination of the grazer community can provide a wealth of information. Temporal changes in grazer biomass can be used to infer the efficiencies of transfer between phytoplankton and grazers (e.g., Verity et al. 1993). Knowledge of the sizestructure of the microzooplankton community can also be valuable as it likely influences exploitation of the microzooplankton by high trophic levels. For example, the grazing rates for copepods feeding on tintinnid ciliates or non-loricate ciliates apparently vary greatly 
with ciliate size (e.g., Gifford \& Dagg 1988, Cariou et al. 1999). We urge then that experiments designed to estimate microzooplankton grazing focus on the predators as well as the prey.

Acknowledgements. This work was supported by the Office of Fellowships and Grants of the Smithsonian Institution. Additional funding was supplied by the Smithsonian Environmental Sciences Program and the US Environmental Protection Agency through grant R826943. Technical support was provided by Sharyn Hedrick, Sam Benson, Darrick Sparks, and Karen Yee. The critiques of previous versions of this paper by Dave Caron, Robert Sanders, David Montagnes, Barry and Evelyn Sherr, Diane Stoecker, Peter Verity, and the anonymous reviewers are gratefully acknowledged.

\section{LITERATURE CITED}

Ayukai T (1996) Possible limitation of the dilution technique for estimating growth and grazing mortality rates of picoplanktonic cyanobacteria in oligotrophic tropical waters. J Exp Mar Biol Ecol 198:101-111

Ayukai T, Miller D (1998) Phytoplankton biomass, production and grazing mortality in Exmouth Gulf, a shallow embayment on the arid, tropical coast of Western Australia. J Exp Mar Biol Ecol 225:239-251

Boyd PW, Muggli DL, Varela DE, Goldblatt RH, Chretien R, Orians KJ, Harrison PJ (1996) In vitro iron enrichment experiments in the NE subarctic Pacific. Mar Ecol Prog Ser 136:179-193

Brown SL, Landry MR, Barber RT, Campbell L, Garrison DL, Gowing MM (1999) Picophytoplankton dynamics and production in the Arabian Sea during the 1995 Southwest Monsoon. Deep-Sea Res ll 46:1745-1768

Burkill PH, Edwards ES, Landry M, Paranjape M, Reckermann M, Sieracki ME, Sleigh MA, Stoecker DK, Verity PG (1993a) Microzooplankton herbivory. In: Ducklow HW (ed) Revised JGOFS Protocols. Intergovernmental Oceanographic Commission, Paris, p 185-191

Burkill PH, Edwards ES, John AWG, Sleigh MA (1993b) Microzooplankton and their herbivorous activity in the northeastern Atlantic Ocean. Deep-Sea Res II 40:479-493

Burkill PH, Leakey RJG, Owens NJP, Mantoura RFC (1993c) Synechococcus and its importance to the microbial foodweb of the northwestern Indian Ocean. Deep-Sea Res II 40:773-782

Burkill PH, Edwards ES, Sleigh MA (1995) Microzooplankton and their role in controlling phytoplankton growth in the marginal ice zone of the Bellinghausen Sea. Deep-Sea Res II 42:1277-1290

Cariou JB, Dolan JR, Dallot S (1999) A preliminary study of tintinnid diversity in the NW Mediterranean Sea. J Plankton Res 21:1065-1075

Caron DA, Dennett MR (1999) Phytoplankton growth and mortality during the 1995 Northeast Monsoon and Spring Intermonsoon in the Arabian Sea. Deep-Sea Res II 46: $1665-1690$

Chavez FP, Buck KR, Service SK, Newton J, Barber RT (1996) Phytoplankton variability in the central and eastern tropical Pacific. Deep-Sea Res II 43:835-870

Cotano U, Uriarte I, Villate F (1998) Herbivory of nanozooplankton in polyhaline and euhaline zones of a small temperate estuarine system (Estuary of Mundaka): seasonal variations. J Exp Mar Biol Ecol 227:265-279
Crawford DW, Stoecker DK (1996) Carbon content, dark respiration and mortality of the mixotrophic planktonic ciliate Strombidium capitatum. Mar Biol 126:415-422

Dagg MJ (1995) Ingestion of phytoplankton by the micro- and mesozooplankton communities in a productive subtropical estuary. J Plankton Res 17:845-857

Detmer AE, Giesenhagen HC, Trenkel VM, Auf dem Venne $\mathrm{H}$, Jochem FJ (1993) Phototrophic and heterotrophic picoand nanoplankton in the anoxic depths of the central Baltic Sea. Mar Ecol Prog Ser 99:197-203

Dolan JR (1991) Guilds of ciliate microzooplankton in the Chesapeake Bay. Estuar Coast Shelf Sci 33:137-152

Dolan JR, Gallegos CL (1991) Trophic coupling of rotifers, microflagellates, and bacteria during fall months in the Rhode River Estuary. Mar Ecol Prog Ser 77:147-156

Dolan JR, Gallegos CL (1992) Trophic role of planktonic rotifers in the Rhode River Estuary, spring-summer 1991. Mar Ecol Prog Ser 85:187-199

Dolan JR, Marrasé C (1995) Planktonic ciliate distribution relative to a deep chlorophyll maximum: Catalan Sea, N. W. Mediterranean, June 1993. Deep-Sea Res 42:1965-1987

Dolan JR, Simek K (1999) Diel periodicity in Synechococcus populations and grazing by heterotrophic nanoflagellates: analysis of food vacuole content. Limnol Oceanogr 44: 1565-1570

Dolan JR, Vidussi F, Claustre H (1999) Planktonic ciliates in the Mediterranean Sea: longitudinal trends. Deep-Sea Res 46:2025-2039

Edwards ES, Burkill PH, Stelfox CE (1999) Zooplankton herbivory in the Arabian Sea during and after the SW monsoon, 1994. Deep-Sea Res II 46:843-863

Elser JJ, Stabler LB, Hassett RP (1995) Nutrient limitation of bacterial growth and rates of bacterivory in lakes and oceans: a comparative study. Aquat Microb Ecol 9: 105-110

Evans GT, Paranjape MA (1992) Precision of estimates of phytoplankton growth and microzooplankton grazing when functional response of grazers may be nonlinear. Mar Ecol Prog Ser 80:285-290

Fahnenstiel GL, McCormick MJ, Lang GA, Redalje DG, Lohrenz SE, Markowitz M, Wagoner B, Carrick HJ (1995) Taxon-specific growth and loss rates for dominant phytoplankton populations from the northern Gulf of Mexico. Mar Ecol Prog Ser 117:229-239

Froneman PW, Balarin MG (1998) Structure and grazing impact of the protozooplankton community in the waters surrounding the Prince Edward Islands (Southern Ocean). Polar Biol 20:198-205

Froneman PW, McQuaid CD (1997) Preliminary investigation of the ecological role of microzooplankton in the Kariega Estuary, South Africa. Estuar Coast Shelf Sci 45:689-695

Froneman PW, Perissinoto R (1996a) Microzooplankton grazing and protozooplankton community structure in the South Atlantic and in the Atlantic sector of the Southern Ocean. Deep-Sea Res I 43:703-721

Froneman PW, Perissinoto R (1996b) Structure and grazing of the microzooplankton communities of the Subtropical Convergence and a warm-core eddy in the Atlantic sector of the Southern Ocean. Mar Ecol Prog Ser 135:237-245

Froneman PW, Perissinotto R, McQuaid CD (1996a) Dynamics of microplankton communities at the ice-edge zone of the Lazarev Sea during a summer drogue study. J Plankton Res 18:1455-1470

Froneman PW, Perissinotto R. McQuaid CD (1996b) Seasonal variations in microzooplankton grazing in the region of the Subtropical Convergence. Mar Biol 126:433-442

Froneman PW, Pakhomov EA, Perissinotto R, Laubscher RK, 
McQuaid CD (1997) Dynamics of the plankton communities of the Lazarev Sea (Southern Ocean) during seasonal ice melt. Mar Ecol Prog Ser 149:201-214

Gallegos CL (1989) Microzooplankton grazing on phytoplankton in the Rhode River, Maryland: nonlinear feeding kinetics. Mar Ecol Prog Ser 57:23-33

Gallegos CL, Jordan TE (1997a) Seasonal progression of factors limiting phytoplankton pigment biomass in the Rhode River estuary, Maryland (USA). I. Controls on phytoplankton growth. Mar Ecol Prog Ser 161:185-198

Gallegos CL, Jordan TE (1997b) Seasonal progression of factors limiting phytoplankton pigment biomass in the Rhode River estuary, Maryland (USA). II. Modeling N vs P limitation. Mar Ecol Prog Ser 161:185-198

Gallegos CL, Jordan TE, Correll DL (1992) Event-scale response of phytoplankton to watershed inputs in a subestuary: timing, magnitude, and location of phytoplankton blooms. Limnol Oceanogr 37:813-828

Gallegos CL, Vant WN, Safi KA (1996) Microzooplankton grazing of phytoplankton in Manukau Harbour, New Zealand. NZ J Mar Freshw Res 30:423-434

Gallegos CL, Jordan TE, Correll DL (1997) Interannual variability in spring bloom timing and magnitude in the Rhode River, Maryland (USA): observations and modeling. Mar Ecol Prog Ser 154:27-47

Gaul W, Antia AN, Koeve W (1999) Microzooplankton grazing and nitrogen supply of phytoplankton growth in the temperate and subtropical northeast Atlantic. Mar Ecol Prog Ser 189:93-104

Gifford DJ (1988) Impact of grazing by microzooplankton in the Northwest Arm of Halifax Harbour, Nova Scotia. Mar Ecol Prog Ser 47:249-258

Gifford DJ, Dagg MJ (1988) Feeding of the estuarine copepod Acartia tonsa Dana: carnivory vs herbivory in natural microplankton assemblages. Bull Mar Sci 43:458-468

Gifford DJ, Fessenden LM, Garrahan PR, Martin E (1995) Grazing by microzooplankton and mesozooplankton in the high-latitude North Atlantic Ocean: spring versus summer dynamics. J Geophys Res C4 100:6665-6675

Harrison WG, Head EJH, Horne EPW, Irwin B, Li WKW, Longhurst AR, Paranjape MA, Platt T (1993) The western North Atlantic Bloom Experiment. Deep-Sea Res II 40:279-305

James MR, Hall JR (1998) Microzooplankton grazing in different water masses associated with the Subtropical Convergence round the South Island, New Zealand. Deep-Sea Res I 45:1689-1707

Jeong HJ, Shim JH, Lee CW, Kim JS, Koh SM (1999) Growth and grazing rates of the marine planktonic ciliate Strombidinopsis sp. on red-tide and toxic dinoflagellates. J Eukaryot Microbiol 46:69-76

Johnson Z, Landry ML, Bidigare RR, Brown SL, Campbell L, Gunderson J, Marra J, Trees C (1999) Energetics and growth kinetics of a deep Prochlorococcus spp. population in the Arabian Sea. Deep-Sea Res II 46:1719-1743

Jones Rl, Young JM (1998) Control of bacterioplankton growth and abundance in deep, oligotrophic Loch Ness (Scotland). Aquat Microb Ecol 15:15-24

Jordan TE, Correll DL, Miklas J, Weller DE (1991a) Nutrients and chlorophyll $a$ at the interface of a watershed and an estuary. Limnol Oceanogr 36:251-267

Jordan TE, Correll DL, Mikias J, Weller DE (1991b) Longterm trends in estuarine nutrients and chlorophyll, and short-term effects of variation in watershed discharge. Mar Ecol Prog Ser 75:121-132

Kamiyama T (1994) The impact of grazing by microzooplankton in northern Hiroshima Bay, the Seto Inland Seam, Japan. Mar Biol 119:77-88
Kemp PF (1994) Microbial carbon utilization on the continental shelf and slope during the SEEP-Il experiment. DeepSea Res II 41:563-581

Kuipers BR, Witte HJ (1999) Grazing impact of microzooplankton on different size classes of algae in the North Sea in early spring and mid-summer. Mar Ecol Prog Ser 180 93-104

Landry MR (1993) Estimating rates of growth and grazing mortality of phytoplankton by the dilution method. In: Kemp PF, Sherr B, Sherr E, Cole JJ (eds) Handbook of methods in aquatic microbial ecology. Lewis Publishers, Ann Arbor, MI, p 715-772

Landry MR, Hassett RP (1982) Estimating the grazing impact of marine microzooplankton. Mar Biol 67:283-288

Landry MR, Monger BC, Selph KE (1993) Time-dependency of microzooplankton grazing and phytoplankton growth in the subarctic Pacific. Prog Oceanogr 32:205-222

Landry MR, Constantinou J, Kirshtein J (1995a) Microzooplankton grazing in the central equatorial Pacific during February and August 1992. Deep-Sea Res II 42:657-671

Landry MR, Kirshtein J, Constantiou J (1995b) A refined technique for measuring the community grazing impact of microzooplankton, with experimental tests in the central equatorial Pacific. Mar Ecol Prog Ser 120:53-63

Landry MR, Brown SL, Campbell L, Constaninou J, Liu H (1998) Spatial patterns in phytoplankton growth and microzooplankton grazing in the Arabian Sea during monsoon forcing. Deep-Sea Res II 45:2353-2368

Latasa M, Landry MR, Schlüter L, Bidigare RR (1997) Pigment-specific growth and grazing rates of phytoplankton in the central equatorial Pacific. Limnol Oceanogr 43: $289-298$

Lehrter JC, Pennock JR, McManus GB (1999) Microzooplankton grazing and nitrogen excretion across a surface estuarine-coastal interface. Estuaries 22:113-125

Lessard EJ, Murrell MC (1998) Microzooplankton herbivory and phytoplankton growth in the northwestern Sargasso Sea. Aquat Microb Ecol 16:173-188

McManus GB, Ederington-Cantrell MC (1992) Phytoplankton pigments and growth rates, and microzooplankton grazing in a large temperate estuary. Mar Ecol Prog Ser 87: $77-85$

Montagnes DJS (1996) Growth responses of planktonic ciliates in the genera Strobilidium and Strombidium. Mar Ecol Prog Ser 130:241-254

Montagnes DJS, Lessard EJ (1999) Population dynamics of a marine planktonic ciliate Strombidinopsis multiauris: its potential to control phytoplankton blooms. Aquat Microb Ecol 20:167-181

Murrell MC, Hollibaugh JT (1998) Microzooplankton grazing in northern San Francisco Bay measured by the dilution method. Aquat Microb Ecol 15:53-63

Nejstgaard JC, Gismervik I, Solberg PT (1997) Feeding and reproduction by Calanus finmarchicus, and microzooplankton grazing during mesocosm blooms of diatoms and the coccolithophore Emiliania huxleyi. Mar Ecol Prog Ser $147: 197-217$

Neuer S, Cowles TJ (1994) Protist herbivory in the Oregon upwelling system. Mar Ecol Prog Ser 113:147-162

Reckermann M, Veldhuis MJW (1997) Trophic interactions between picophytoplankton and micro- and nanozooplankton in the western Arabian Sea during the NE monsoon 1993. Aquat Microb Ecol 12:263-273

Rivkin RB, Putland JN, Anderson MR, Deibel D (1999) Microzooplankton bacterivory and herbivory in the NE subarctic Pacific. Deep-Sea Res II 46:2579-2618

Ruiz A, Franco J, Villate F (1998) Microzooplankton grazing 
in the Estuary of Mundaka, Spain, and its impact on phytoplankton distribution along the salinity gradient. Mar Ecol Prog Ser 14:281-288

Scharek R, Van Leeuwe MA, De Baar HJW (1997) Response of Southern Ocean phytoplankton to the addition of trace metals. Deep-Sea Res 1l 44:209-227

Schülter L (1998) The influence of nutrient addition on growth rates of phytoplankton groups and microzooplankton grazing rates in a mesocosm experiment. J Exp Mar Biol Ecol 228:53-71

Sime-Ngando T, Gosselin M, Roy S, Chanut JP (1995) Significance of planktonic ciliated protozoa in the Lower St. Lawrence Estuary: comparison with bacterial, phytoplankton, and particulate organic carbon. Aquat Microb Ecol 9:243-258

Stoecker DK, Michaels AE (1991) Respiration, photosynthesis and carbon metabolism in planktonic ciliates. Mar Biol 108:441-447

Strom SL, Strom MW (1996) Microplankton growth, grazing, and community structure in the northern Gulf of Mexico. Mar Ecol Prog Ser 130:229-240

Tamigneaux E, Mingelbier M, Klein B, Legendre L (1997) Grazing by protists and seasonal changes in the size structure of protozooplankton and phytoplankton in a temperate nearshore environment (western Gulf of St. Lawrence, Canada). Mar Ecol Prog Ser 146:231-247

Editorial responsibility: Otto Kinne (Editor), Oldendorf/Luhe, Germany
Tsuda A, Kawaguchi S (1997) Microzooplankton grazing in the surface water of the Southern Ocean during an austral summer. Polar Biol 18:240-245

Verity PG, Vernet M (1992) Microzooplankton grazing, pigments, and composition of plankton communities during late summer in two Norwegian fjords. Sarsia 77:263-274

Verity PG, Stoecker DK, Sieracki ME, Nelson JR (1993) Grazing, growth and mortality of microzooplankton during the 1989 North Atlantic spring bloom at $47^{\circ} \mathrm{N}, 18^{\circ} \mathrm{W}$. DeepSea Res 1 40:1793-1814

Verity PG, Stoecker DK, Sieracki ME, Nelson JR (1996) Microzooplankton grazing of primary production at $140^{\circ} \mathrm{W}$ in the equatorial Pacific. Deep-Sea Res II 43:1227-1255

Waterhouse TY, Welschmeyer NA (1995) Taxon-specific analysis of microzooplankton grazing rates and phytoplankton growth rates. Limnol Oceanogr 40:827-834

Weeks A, Conte MH, Harnis RP, Bedo A, Bellan l, Burkill PH, Edwards ES, Harbour DS, Kennedy H, Llewllyn C, Mantoua RFC, Morales CE, Pomroy AJ, Turley CM (1993) The physical and chemical environment and changes in community structure associated with bloom evolution: the Joint Flux Study North Atlantic Bloom Experiment. DeepSea Res II 40:347-368

Wickham S, Carstens M (1998) Effects of ultraviolet-B radiation on two arctic microbial food webs. Aquat Microb Ecol 16:163-171

Submitted: February 14, 2000; Accepted: May 11, 2000

Proofs received from author(s): June 19, 2000 